DAKWATUNA

Jurnal Dakwah dan Komunikasi Islam

Volume 6, Nomor 2, Agustus 2020

\title{
Konstruksi Sosial Keagamaan Masyarakat Pada Masa Pandemi Covid-19
}

\author{
Putri Nadiyatul Firdausi \\ Institut Agama Islam Syarifuddin Lumajang, Indonesia \\ Email: putrinadiyatul@gmail.com
}

\author{
Abdul Ghofur \\ Institut Agama Islam Syarifuddin Lumajang, Indonesia \\ Email: abdul.ghofur020382@gmail.com \\ Bambang Subahri \\ Institut Agama Islam Syarifuddin Lumajang, Indonesia \\ Email: bambang.subahri@gmail.com
}

\begin{abstract}
Covid-19 or Corona pandemic, which has entered Indonesia since the last three months, has changed many of the religious behaviors of Indonesian people who are predominantly Muslim. Starting from praying in congregation at home, Friday prayers at home, Eid prayer at home, changing sentences on some words in the call to prayer to cancel the departure of the pilgrims. This has changed the religious traditions and religious behavior of the community in general. This study uses theoretical conceptions according to Peter L. Berger with the conception of social construction with three components, namely externalization, objectivation and internalization. This study uses a qualitative approach with the aim of uncovering a phenomenon of religious behavior that occurred in the community during the Covid-19. The conclusions in this research are, externally the community made social changes because of information related to the Covid-19 pandemic, both through a task force formed by the government, as well as news that circulated on television and social media. From that, people make objectivation by implicit behavior formation in response to government regulations and news circulating on social media. Internalization is carried out by the public by picking wisdom in every situation that occurs. Furthermore, from the socio-religious construction the perspective of Sufism during the pandemic resulted in patterns of religious behavior: patient, gratitude, tawakal and muhasabah
\end{abstract}

Keywords: Covid-19, Social Construction, Tasawuf, Society

\section{Abstrak}

Covid-19 atau Corona yang telah masuk ke Indonesia sejak tiga bulan terakhir telah mengubah banyak perilaku keagamaan masyarakat Indonesia yang 
mayoritas beragama Islam. Mulai dari shalat berjamaah di rumah, shalat Jumat di rumah, shalat idul fitri di rumah, perubahan kalimat pada sebagian kata dalam azan hingga pembatalan pemberangkatan jemaah haji. Hal demikian telah mengubah tradisi keagamaan dan perilaku beragama masyarakat secara umum. Penelitian ini menggunakan konsepsi teoritik menurut Peter L. Berger dengan konsepsi konstruksi sosial dengan tiga komponennya yaitu eksternalisasi, objektivasi dan internalisasi. Penelitian ini menggunakan pendekatan kualitatif dengan tujuan mengungkap sebuah fenomena perilaku beragama yang terjadi di tengah masyarakat pada masa pandemi Covid-19 atau Corona. Adapun simpulan dalam penelitian ini ialah, secara eksternal masyarakat melakukan perubahan sosial karena adanya informasi-informasi terkait pandemi Covid-19, baik melalui gugus tugas yang dibentuk pemerintah, maupun berita-berita yang beredar di televisi dan media sosial. Dari itu masyarakat melakukan objektivasi dengan pembentukan perilaku yang dilakukan secara implisit untuk menanggapi peraturan pemerintah maupun berita yang beredar di media sosial. Internalisasi dilakukan masyarakat dengan memetik hikmah dalam setiap keadaan yang terjadi. Selanjutnya dari konstruksi sosial keagamaan perspektif tasawuf pada masa pandemi mengasilkan pola perilaku agama: sabar, syukur, tawakal dan muhasabah.

Kata Kunci: Covid-19, Konstruksi Sosial, Tasawuf, Masyarakat

\section{PENDAHULUAN}

Dalam tiga bulan terakhir, tatanan sosial dan perilaku sosial mengalami banyak perubahan karena pandemi Virus Corona yang melanda hampir seluruh negara di dunia, yang dikenal dengan sebutan Covid-19. ${ }^{1}$ Perubahan ini tidak hanya berdampak bagi kesehatan dan perekonomian, namun perilaku keberagamaan juga mengalami gelombang pasang, khususnya di kalangan umat Islam. Perilaku keberagamaan umat Islam mengalami perubahan, yang

\footnotetext{
${ }^{1}$ Coronavirus merupakan jenis virus yang menyebabkan penyakit pada manusia dan hewan pada umumnya. Kejadian pada manusia biasanya menyebabkan penyakit infeksi saluran pernapasan, flu biasa hingga penyakit yang serius yang terjadi seperti Middle East Respiratory Syndrome (MERS) dan Sindrom Pernafasan Akut Berat Severe Acute Respiratory Syndrome (SARS). Coronavirus ini baru ditemukan yangmenjangkit manusia pada sejak kejadian luar biasa muncul di Wuhan Cina, pada Desember 2019, selanjutnya diberi nama Severe Acute Respiratory Syndrome Coronavirus 2 (SARS-COV2) dan kemudian dikenal dengan sebutan Coronavirus Disease-2019 (COVID-19). Dikutip dari: Promkes Kementerian Kesehatan RI dan Perhimpunan Dokter Paru Indonesia. Informasi Tentang Virus Corona. Dari: https://stoppneumonia.id/informasi-tentang-virus-corona-novel-coronavirus/
} 
biasanya dengan gampang melakukan ibadah bersama, lantas berubah dan tidak segampang itu lagi saat ini².

Sejak ditemukannya Covid-19 ini di Wuhan China pada bulan Desember 2019 hingga saat ini, dunia masih diselimuti rasa cemas dan ketakutan. Bahkan, hingga detik ini di Wuhan masih ditemukan pasien positif Covid-19. Covid-19 telah banyak menyisakan puing-puing ketakutan pada setiap masyarakat di dunia, tidak terkecuali di Indonesia bahkan hingga detik ini. ${ }^{3}$

Pada tanggal 2 Maret 2020 pemerintah mengumumkan dua kasus pasien positif Covid-19 di Indonesia yang ditengarai pertama kali. Ini berbeda dengan pendapat Pakar Epidemiologi Universitas Indonesia (UI) Pandu Riono yang menyebutkan bahwa virus Covid-19 yang sejenis SARS-CoV-2 itu sudah masuk ke Indonesia sejak awal Januari. ${ }^{4}$

Selanjutnya, Mendagri Tito Karnavian mengeluarkan Surat Edaran Nomor 440/2622/SJ tentang Pembentukan Gugus Tugas Percepatan Penanganan Covid-19 di daerah. Aturan ini dikeluarkan pada Minggu 29 Maret 2020. Direktur Manajemen Penanggulangan Bencana dan Kebakaran Kementerian Dalam Negeri, Syafrizal, mengatakan bahwa keberadaan Surat Edaran itu bertujuan agar kepala daerah menjadi ketua gugus tugas percepatan penanganan Covid-19 yang berada di daerah. ${ }^{5}$

\footnotetext{
${ }^{2}$ M. Muafi bin Thohir, M. M. B. (2020). Manajemen Dakwah Dalam Meningkatkan Perilaku Beribadah Santri Pondok Pesantren Darun Najah Petahunan Kecamatan Sumbersuko Lumajang. Dakwatuna: Jurnal Dakwah dan Komunikasi Islam, 6(01), 1-23.

3 Yosa Shinta Dewi. Terungkap Fakta Baru Terkait Ganasnya Virus Corona, Pasien Covid19 di Kota Wuhan Alami Perubahan Warna Kulit, Seperti Terbakar dan Sangat Gelap. Selasa, 21 April 2020 | 09:58 WIB dari: https://hits.grid.id/read/482114982/terungkap-fakta-baru-terkaitganasnya-virus-corona-pasien-covid-19-di-kota-wuhan-alami-perubahan-warna-kulit-sepertiterbakar-dan-sangat-gelap?page=all

4 Ellyvon Pranita. Diumumkan Awal Maret, Ahli: Virus Corona Masuk Indonesia dari Januari. Kompas.com - 11/05/2020, 13:06 WIB dari: https://www.kompas.com/sains/read/2020/05/11/130600623 /diumumkan-awal-maret-ahli-virus-corona -masuk-indonesia-dari-januari.

5 Dian Erika Nugraheny. Mendagri Keluarkan Surat Edaran soal Pembentukan Gugus Tugas Penanganan Covid-19 di Daerah. Kompas.com - 30/03/2020, 11:23 WIB. dari: https://nasional.kompas.com/read/2020/03/30/11234971/mendagri- keluarkan-surat-edaransoal-pembentukan-gugus-tugas-penanganan
} 
Perhatian negara dan dunia terfokus pada penanganan pandemi yang besar dan meresahkan masyarakat ini. Berbagai kebijakan dikeluarkan dan anggaran besarpun dialokasikan untuk mengatasinya. Beberapa kebijakan yang dikeluarkan negara Indonesia di antaranya Sosial Distancing, karantina kesehatan, yang kemudian dituangkan dalam PP Nomor 21 Tahun 2020 tentang Pembatasan Sosial Berskala Besar (PSBB). Anggaran yang dialokasikan untuk penanggulangan Covid-19 pun mencapai Rp 405, 1 triliun. Seiring pesatnya wabah Covid-19 di Indonesia, berbagai peraturan pemerintah diturunkan silih berganti, di antaranya mengenai bantuan sosial yang mengatasnamakan Covid19. Bahkan, banyak terjadi ketimpangan dan penyelewengan, baik konflik di antara sesama masyarakat di tatanan bawah, konflik dengan pemerintah, konflik dengan tokoh agama, dengan perusahaan-perusahaan, karena sebagian besar perusahaan telah melakukan PHK pada karyawannya.

Di antara konflik yang terjadi antara masyarakat dengan pemerintah adalah adanya respon negatif atas kebijakan yang berlaku, salah satunya terkait Bantuan Langsung Tunai (BLT). Menurut Wakil Direktur Institute for Development of Economics and Finance (Indef), Eko Listiyanto, hal ini disebabkan tidak konsistennya pemerintah dalam mengambil sebuah kebijakan. ${ }^{6}$ Hal demikian juga diperkuat adanya ketimpangan dan konflik sosial di tataran aparatur desa, sebagaimana diungkapkan dalam Tribunbanyumas.com tentang Dilema, sejumlah Kades yang enggan salurkan BLT pada masyarakat terdampak Covid-19. Pemerintah mengalokasikan bantuan langsung tunai (BLT) bagi masyarakat miskin terdampak virus Covid-19 sebesar Rp 600.000 perbulan, perkepala keuarga. Potensi persoalan sudah muncul di lapangan. Adapun

6 Alokasi anggaran sebesar Rp 405,1 triliun guna penanganan Covid-19 dinilai Eko sebetulnya sudah cukup besar, meskipun belum ideal apabila dibandingkan dengan negaranegara lain. Namun yang kurang dari anggara tersebut adalah aspek kecepatan sekaligus ketepatan penyaluran anggaran. "Ketika baru diumumkan, ekspektasi masyarakat terkait program social safety net sebetulnya begitu tinggi. Tetapi ketika diimplementasikan berbenturan dengan aspek data yang tidak valid, akurasi data yang sebagian belum tepat sasaran," Eko Listiyanto melalui telekonferensi. (26/4/2020). Lihat: BeritaSatu.com dari: https://www.beritasatu.com/ekonomi/625409-blt-tidak-tepat-sasaran-bisa-picu-konflik-sosial 
musababnya adalah kekhawatiran akan terjadi konflik sosial antarwarga sebab bantuan tidak merata.7

Berdasar data dari Kementerian Ketenagakerjaan, hingga 1 Mei tahun 2020, sudah ada sejumlah 1.722 .958 pekerja dari sektor formal dan informal yang dirumahkan atau di-PHK. Jumlah itu merupakan data yang baru terverifikasi. Masih ada sekitar 1,2 juta pekerja yang sedang divalidasi datanya oleh Kementerian Ketenagakerjaan. Artinya, jumlah orang yang kehilangan pekerjaan bisa mencapai 3 juta selama pandemi ini. ${ }^{8}$ Sejak virus corona merebak dan menjadi pandemi, kasus PHK terus terjadi. Data Kementerian Tenaga Kerja per 20 April 2020 menyebutkan, hampir tiga juta karyawan dirumahkan atau terkena PHK. ${ }^{9}$

Umat Islam sebagai umat mayoritas di Indonesia harus menyikapi hal ini dalam perspektif Islam dan seobyektif mungkin. Media massa, baik di negeri berpenduduk mayoritas Islam, maupun di negara-negara berpenduduk mayoritas non-Muslim, perlu pula mengetahui kebijaksanaan Islam dalam menghadapi pandemi. Dengan demikian, ini bisa jadi momentum menggerus Islamophobia yang kadang masih melekat ${ }^{10}$.

Perspektif agama ini memiliki pengaruh sangat kuat dalam menyadarkan masyarakat untuk melakukan tindakan tertentu, termasuk dalam menghadapi wabah Covid-19 ini. ${ }^{11}$ Oleh karenanya, masalah yang akan dibahas dalam artikel

\footnotetext{
${ }^{7}$ Yayan isro roziki. Dilema, Sejumlah Kades Enggan Salurkan BLT Masyarakat Terdampak Corona, Khawatir Ada Konflik Sosial. Sabtu, 18 April 2020 16:05 dari: https://banyumas.tribunnews.com ／2020/04/18/dilema-sejumlah-kades-enggan-salurkan-bltmasyarakat-terdampak-corona-khawatir-ada-konflik-sosial

${ }^{8}$ Cahyo Prayogo. Virus PHK Tak Kalah Seram dari Virus Corona. Minggu, 10 Mei 2020 12:58 WIB dari: https://www.wartaekonomi.co.id/read284882/virus-phk-tak-kalah-seram-dari-viruscorona

${ }^{9}$ Heru Margianto. Badai PHK di Tengah Corona Kompas.com 04/05/2020, 09:23 WIB dari: https://www.kompas.com/tren/read /2020/05/04/092323965/badai-phk-di-tengahcorona?page $=1$

${ }^{10}$ Rio Febriannur Rachman. (2018). Perspektif Karen Armstrong Tentang Islamofobia Di Media Barat. Dakwatuna: Jurnal Dakwah dan Komunikasi Islam, 4(2), 282-291.

11 Jenal Bustomi., Siti Sanah., Zulli Umri Siregar. MENYIKAPI WABAH PENYAKIT COVID-19 DALAM BERTASAWUF. Fakultas Tarbiyah dan Keguruan UIN Sunan Gunung Djati Bandung
} 
ini adalah bagaimana menyikapi wabah penyakit Covid-19 ditinjau dari konstruksi sosial keagamaan, baik dalam tatanan pemerintah secara umum maupun pada organisasi terbesar Islam di Indonesia seperti MUI, NU dan Muhammadiyah.

Lebih lanjut, Sekretaris Komisi Fatwa Majelis Ulama Indonesia (MUI) Asrorun Niam Sholeh mengimbau agar penyelenggaraan shalat Jumat dihentikan sementara selama virus Covid-19 masih mewabah di Indonesia. Imbauan ini diperuntukkan bagi wilayah dengan tingkat penyebaran virus Covid-19 tinggi atau zona merah. ${ }^{12}$ Tidak hanya pembatasan pada shalat Jumat, merujuk Fatwa MUI No 14 tahun 2020, Dewan Pertimbangan MUI menyebut pelaksanaan ibadah tarawih menyesuaikan dengan kondisi di daerah masingmasing. ${ }^{13}$

Kegiatan dakwah yang melibatkan masyarakat luas, semacam tabligh akbar pun dibatasi. Dengan demikian, para dai dituntut mampu menghadapi tantangan zaman ini ${ }^{14}$. Yang mana sejak dahulu, para dai memang harus bisa menyampaikan kebenaran dalam segala situasi. Perubahan kondisi masyarakat bukan berarti cuti tugas dakwah. Dakwah dengan berlandaskan azas kebaikan dan keramahtamahan khas Nabi Muhammad tetap harus berjalan ${ }^{15}$. Meski memang, strateginya bakal berbeda. Yang jelas, tetap mengedepankan kearifan lokal dan kultur masyarakat setempat ${ }^{16}$.

\footnotetext{
${ }^{12}$ Fitria Chusna Farisa. MUI Imbau Penundaan Sementara Shalat Jumat di Kawasan Berisiko Virus Corona. Kompas.com - 20/03/2020, 11:38 WIB dari: https://nasional.kompas.com/read/2020/03/20 / /11380221/mui-imbau-penundaan-sementarashalat-jumat-di-kawasan-berisiko-virus-corona.

13 (Zahrotul Oktaviani/ Red: Muhammad Fakhruddin. MUI: Pelaksanaan Tarawih Menyesuaikan Kondisi di Daerah. Rabu 22 Apr 2020 16:13 WIB. dari: https://republika.co.id/berita/q96mz0327/mui-pelaksanaan-tarawih-menyesuaikan-kondisi-didaerah

${ }^{14}$ Abdul Ghofur. (2019). Dakwah Islam Di Era Milenial. Dakwatuna: Jurnal Dakwah dan Komunikasi Islam, 5(2), 136-149.

15 Faiqotul Mala. (2020). Mengkaji Tradisi Nabi Sebagai Paradigma Dakwah Yang Ramah. Dakwatuna: Jurnal Dakwah dan Komunikasi Islam, 6(01), 104-127.

${ }^{16}$ Rio Febriannur Rachman. (2018). Dakwah Intraktif Kultural Emha Ainun Nadjib. Jurnal Spektrum Komunikasi, 6(2), 1-9.
} 
Covid-19 secara umum telah mengubah kebiasaan umat dalam Islam beribadah. Ibadah sholat Jumat yang wajib dilaksanakan secara berjamaah minimal oleh 40 orang di masjid, berpotensi besar ditiadakan. Dilansir dari laman Dawn Arab Saudi tak hanya menutup masjid, tetapi juga mengubah kalimat azan ketika dikumandangkan sebagai peringatan atau panggilan. Biasanya azan menyerukan agar umat Muslim untuk sholat jamaah di masjid. Namun kini kalimat azan itu diubah dengan mengarahkan agar masyarakat melaksanakan sholat di rumah. ${ }^{17}$

Pemerintah juga memutuskan untuk tidak memberangkatan jemaah haji pada tahun 2020 ini. Keputusan ini disampaikan berdasarkan Keputusan Menteri Agama Republik Indonesia Nomor 494 Tahun 2020 tentang pembatalan keberangkatan jemaah haji pada penyelenggaraan tahun 1441 Hijriah atau tahun 2020. Tidak hanya di negeri ini, sejumlah negara memutuskan untuk tidak memberangkatkan jemaahnya, karena situasi pandemi covid-19 semakin melanda. ${ }^{18}$

\section{PEMBAHASAN}

1. Konstruksi Sosial Keagamaan Masyarakat pada Masa Pandemi Covid-19

Teori konstruksi sosial (social construction) tentu tidak bisa terlepaskan dari bangunan teoretik yang dikemukakan oleh Peter L. Berger dan Thomas Luckmann. Peter L. Berger merupakan sosiolog dari New School for Social Research. Sementara Thomas Luckman adalah sosiolog dari University of Frankfurt. Teori konstruksi sosial, sejatinya

\footnotetext{
17 (Abu Sahma Pane. Pro Kontra Larangan Sholat Jumat di Tengah Wabah Corona. Kamis $19 \quad$ Maret $2020 \quad 16: 37 \quad$ WIB dari: https://www.okezone.com/tren/read/2020/03/19/620/2185963/pro-kontra -larangan-sholat-jumat-di-tengah-wabah-corona

${ }^{18}$ (Merlion Gusti. Batal Haji Akibat Pandemi Corona, Kemenag Batalkan Haji Tahun 2020. Rabu, 3 Juni 2020 | 11:27 WIB. dari: https://www.kompas.tv/article/84632/batal-haji-akibatpandemi-corona-kemenag-batalkan- haji-tahun-2020
} 
dirumuskan kedua akademisi ini sebagai kajian teoritis dan sistematis mengenai sosiologi.

Istilah konstruksi realitas sosial (social construction of reality) menjadi terkenal sejak diperkenalkan Peter L. Berger dan Thomas Luckman melalui buku The Social Construction of Reality: A Treatise in the Sociological of Knowledge tahun $1966 .{ }^{19}$ la menggambarkan proses sosial melalui tindakan dan interaksinya, di mana individu menciptakan secara terus-menerus suatu realitas yang dimiliki serta dialami bersama secara subyektif. ${ }^{20}$

Pada tahun 1710, Vico dalam "De Antiquissima Italorum Sapientia”, mengungkapkan filsafatnya dengan berkata "Tuhan adalah pencipta alam semesta dan manusia adalah tuan dari ciptaan”. Dia menjelaskan bahwa "mengetahui" berarti "mengetahui bagaimana membuat sesuatu". Ini berarti seseorang itu baru mengetahui sesuatu jika ia menjelaskan unsur-unsuf apa yang membangun sesuatu itu. Menurut Vico, bahwa hanya tuhan sajalah yang dapat mengerti alam raya ini, karena hanya dia yang tahu bagaimana membuatnya dan dari apa ia membuatnya. Sementara itu, orang hanya dapat mengetahui sesuatu yang telah dikontruksikannya ${ }^{21}$.

Berger dan Luckman mengatakan institusi masyarakat tercipta dan dipertahankan dan diubah melalui tindakan dan interaksi. Meskipun masyarakat dan institusi sosial terlihat nyata obyektif, namun pada

\footnotetext{
${ }^{19}$ Proses penyusunan buku oleh kedua sosiolog berlangsung kurang lebih 4 tahun dalam rentang waktu 1962-1966. Bukunya pertama terbit di tahun 1966. Lihat, Peter L Berger and Thomas Luckmann, The Social Construction of Reality Treatise in the Sociology of Knowledge, (New York: 1966). Sudah diterjemahkan ke dalam berbagai bahasa termasuk ke dalam Bahasa Indonesia, lihat Peter L Berger dan Thomas Luckman, Tafsir Sosial atas Kenyataan, (Jakarta : LP3S, 1990).

${ }^{20}$ H.M Burhan Bungin, Sosiologi Komunikasi: Teori Paradigm dan Diskursus Teknologi Komunikasi di Masyarakat, (Jakarta: Prenada Media Grup, 2008), 193.

${ }^{21}$ H.M Burhan Bungin, Sosiologi Komunikasi: Teori Paradigm dan Diskursus Teknologi Komunikasi di Masyarakat, (Jakarta: Prenada Media Grup, 2008), 24
} 
kenyataan semuanya dibangun dalam definisi subyektif melalui proses interaksi pada keduanya.

Objektivitas baru bisa terjadi melalui penegasan berulang-ulang yang diberikan oleh orang lain yang memiliki definisi subyektif. Pada tingkat generalitas paling tinggi, manusia menciptakan dunia dalam makna simbolis yang universal, yaitu pandangan hidupnya yang menyeluruh, yang memberi legitimasi dan mengatur bentuk-bentuk sosial serta memberi makna pada berbagai bidang kehidupannya.

Proses konstruksinya, jika dilihat dari perspektif teori Berger \& Luckman, berlangsung melalui interaksi sosial dialektis dari tiga bentuk yang menjadi entry concept, yakni subjective reality, symbolic reality dan objective reality. Selain itu, konstruksi juga berlangsung dalam suatu proses dengan tiga simultan: eksternalisasi, objektivasi dan internalisasi.

a. Objective reality adalah suatu kompleksitas definisi realitas serta rutinitas tindakan dan tingkah laku yang telah mapan terpola, yang kesemuanya dihayati oleh individu secara umum sebagai fakta.

b. Symblolic reality merupakan semua ekspresi simbolik dari apa yang dihayati sebagai "objective reality", misalnya teks produk industri media, seperti berita di media cetak atau elektronika, begitu pun yang ada di film-film.

c. Subjective reality adalah konstruksi definisi realitas yang dimiliki individu, kemudian dikonstruksi melalui proses internalisasi. Realitas subyektif yang dimiliki masing-masing individu merupakan basis untuk melibatkan diri dalam proses eksternalisasi. ${ }^{22}$

Melalui sentuhan Hegel yakni tesis-antitesis-sintesis, Berger menemukan konsep untuk menghubungkan antara yang subyektif dan

\footnotetext{
${ }^{22}$ Dedy N Hidayat, Konstruksi Sosial Industri Penyiaran: Kerangka Teori Mengamati Pertarungan di Sektor Penyiaran, Makalah dalam diskusi "UU Penyiaran, KPI dan Kebebasan Pers, di Salemba 8 Maret 2003
} 
obyektif melalui konsep dialektika, yang dikenal dengan eksternalisasiobjektivasi-internalisasi.

a. Eksternalisasi adalah penyesuaian diri dengan dunia sosio-kultural sebagai produk manusia. "Society is a human product".

Eksternalisasi merupakan usaha pencurahan atau ekspresi diri manusia ke dalam dunia, baik dalam kegiatan mental maupun fisik. Ini sudah menjadi sifat dasar manusia, selalu mencurahkan diri ke tempat dimana ia berada. Manusia tidak dapat mengerti sebagai ketertutupan yang lepas dari dunia luarnya. Manusia berusaha menangkap dirinya kemudian dihasilkan suatu dunia. Dengan kata lain, manusia menemukan dirinya sendiri dalam suatu dunia. ${ }^{23}$

Penyesuaian diri dengan dunia sosio-kultural pada masyarakat "Society is a human product" selaras dengan pemaparan Ahli Medis Combiphar Sandi Perutama Gani yang menyatakan bahwa covid-19 tidak selalu membawa dampak negatif secara sosiobiologis. la berpendapat bahwa ada beberapa hal positif yang bisa didapat oleh masyarakat. ${ }^{24}$

Tahap eksternalisasi masyarakat juga selaras dengan hasil survei dari McKinsey, yang menyakan bahwa Covid-19 membawa kekhawatiran bagi masyarakat. Kekhawatiran terbesar, dengan angka 62\%, adalah tidak mengetahui berapa lama kondisi ini akan berlangsung. Ini disusul dengan kekhawatiran akan keselamatan diri dan keluarga (61\%), Serta kekhawatiran akan kontribusi dalam penyebaran virus sebesar $45 \%$.

23 Bungin, Sosiologi Komunikasi.,198.

${ }^{24}$ Ade Nasihudin Al Ansori. Perubahan Perilaku Masyarakat yang Terjadi Selama Pandemi COVID-19 di Indonesia. 20 Mei 2020, 09:00 WIB. dari: https://www.liputan6.com/health/read/4258205/ perubahan-perilaku-masyarakat-yang-terjadiselama-pandemi-covid-19-di-indonesia 
Adapun dampak dari kekhawatiran tersebut adalah perubahan perilaku masyarakat menjadi lebih peduli akan kebersihan dan kesehatan, di kalangan menengah atas hingga menengah ke bawah. Dilihat dari hasil survei, 85\% masyarakat lebih memerhatikan kebersihan tangan, 55\% lebih sering mengonsumsi air putih. Lebih lanjut, 47\% lebih banyak mengonsumsi sayur dan buah, dan $18 \%$ lebih sering berolahraga.

Beberapa perubahan perilaku tersebut adalah contoh tahapan eksternalisasi masyarakat dalam pencurahan atau ekspresi diri manusia ke dalam dunia yang jauh berbeda dengan masa sebelum adanya pandemi ini. Ini sudah menjadi sifat dasar manusia, akan selalu mencurahkan diri ke tempat dimana ia berada dengan selalu beradaptasi.

Proses eksternalisasi ini juga diperkuat akan trunya fatwa MUI tentang Hukum Tak Sholat Jumat 3 Kali Berturutan. Sebagaimana yang dikemukakan oleh Asrorun Niam Sholeh yang mengatakan, ada tiga jenis orang yang tidak melaksanakan sholat Jumat. Pertama, orang yang tidak shalat Jumat karena inkar akan kewajiban Jumat, maka dia dihukumi sebagai kafir.

Berikutnya yang kedua, orang Islam yang tidak sholat Jumat karena malas. Ia meyakini bahwa kewajiban Jumat tapi tidak sholat Jumat karena kemalasan dan tanpa adanya uzur syar'i, maka dia berdosa atau 'ashin.

Ketiga adalah orang Islam yang tidak melakukan shalat Jumat karena ada uzur syar'i, maka ini dibolehkan. Menurut pandangan para ulama fikih, uzur syar'i tidak sholat Jumat antara lain sakit. Ketika sakitnya lebih dari 3 kali Jumat, maka ia tidak sholat Jumat tiga kali berturut-turut pun tidak berdosa. 
Sebagaimana yang diterangkan dalam risalah Asna al-Mathalib yang berbunyi:

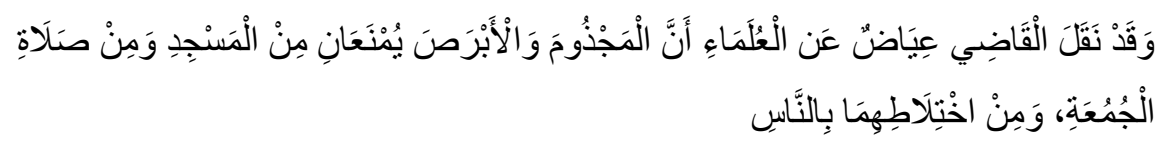

Yang tak lain artinya adalah, orang yang terjangkit penyakit menular dicegah untuk ke masjid dan sholat Jumat, juga bercampur dengan orang-orang (yang sehat).

Dipertegas lagi dalam kitab al-Inshaf yang menyebutkan tentang:

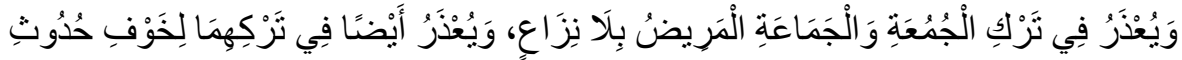

$$
\begin{aligned}
& \text { الْمَرَض }
\end{aligned}
$$

Uzur yang dibolehkan meninggalkan shalat Jumat juga jamaah ialah orang yang sakit tanpa ada perbedaan di kalangan Ulama. Termasuk udzur juga yang dibolehkan meninggalkan sholat Jumat juga jamaah ialah karena takut terjadinya sakit.

Penyebaran Covid-19 akan semakin meluas tatkala terjadi kerumunan manusia dan salah satunya adalah ketika sholat Jumat. Kekhawatiran terjadinya sakit atau tertular virus corona menjadi uzur untuk tidak sholat Jumat dan menggantinya dengan sholat zuhur sebagai proses eksternal dalam kontruksi sosial. ${ }^{25}$

b. Objektivasi adalah interaksi sosial dalam dunia intersubyektif yang dilembagakan atau mengalami institusionalisasi. "Society is an objective reality".

Objektivasi merupakan hasil yang telah dicapai, baik mental maupun fisik dari kegiatan eksternalisasi manusia tersebut. Hasil itu

\footnotetext{
${ }^{25}$ Tim Hikmah detikcom. MUI Jelaskan Hukum Tak Sholat Jumat 3 Kali Berturutan Karena Virus Corona. detikcom - detikNews. dari: https://news.detik.com/berita/d-4962617/mui-jelaskanhukum-tak-sholat-jumat-3-kali-berturutan-karena-virus-corona
} 
menghasilkan realitas obyektif yang bisa jadi akan menghadapi penghasil itu sendiri sebagai suatu faktisitas yang berada di luar dan berlainan dari manusia yang menghasilkannya. ${ }^{26}$

Proposisi bahasa yang terkecil dalam bahasa adalah kata. Berbeda dengan ilmu bahasa mengenai kata dari segala aspeknya, penyelidikan kata dari sisi logika bertujuan mencari pengertian bahasa dari sisi bagaimana penggunaan kata secara tepatnya. Penyelidikan kata ini penting karena merupakan anasir yang membentuk pemikiran dalam konstruksi sosial. ${ }^{27}$

Proses objektivasi adalah interaksi sosial dalam dunia intersubyektif yang dilembagakan atau mengalami institusionalisasi. "Society is an objective reality" tidak terlepas dari konflik sosial hingga terbentuknya subjektifitas dalam kondisi yang tidak menentu di masa pandemi seperti ini.

Juru Bicara Pemerintah untuk Penanganan Covid-19, Achmad Yurianto dengan tegas mengatakan bahwa tren angka penyebaran covid-19 terus naik karena selain sulit untuk mendeteksi Orang Tanpa Gejala (OTG), juga masih banyak warga yang tak patuhi aturan pemerintah dalam memerangi penyebaran Covid-19. Masih ada orang yang positif tanpa gejala di tengah masyarakat yang tidak memiliki kesadaran akan kesehatan diri dan orang lain, dan masih ada masyarakat rentan tertular karena tidak menggunakan masker, tidak cuci tangan, dan lain sebagainya. ${ }^{28}$

\footnotetext{
${ }^{26}$ H.M Burhan Bungin, Sosiologi Komunikasi: Teori Paradigm dan Diskursus Teknologi Komunikasi di Masyarakat, (Jakarta: Prenada Media Grup, 2008), 193.

${ }_{27}$ Mundiri, Logika, (Jakarta: Raja Wali Pers, 2010)., 21

${ }^{28}$ Haky. Masih Banyak Warga Tidak Patuh Aturan Pemerintah untuk Lawan Corona. Senin 06 April 2020 18:30 WIB. Dari: https://megapolitan.okezone.com/read/2020/04/06/338/2195057/masih-banyak-warga-tidakpatuh-aturan-pemerintah-untuk-lawan-corona
} 
Justru proses objektivasi lebih dahulu dijalani oleh kalangan penggerak ekonomi, yakni sejumlah produsen masker yang menyadari dampak pandemi ini. Jumlah produsen masker meningkat drastis selama pandemi Covid-19 di Indonesia. Kementerian Kesehatan mencatat angkanya melonjak hingga 200\%.

Direktur Jenderal Kefarmasian dan Alat Kesehatan (Dirjen Farmalkes) Kementerian Kesehatan (Kemenkes), Engko Sosialine Magdalene, menjelaskan bahwa sebelum wabah virus Covid-19, jumlah produsen masker hanya 26 dan kini yang sudah mendapatkan izin menjadi 83 produsen.

Perizinan sudah diberikan dan bila pada awal tahun hanya ada 26 produsen masker, Saat ini jumlahnya mencapai 83 produsen. Artinya, terdapat peningkatan lebih dari 200\%, yang diketahui melalui data perizinan untuk produsen masker. ${ }^{29}$

c. Internalisasi adalah individu mengidentifikasi diri di tengah lembagalembaga social, di mana individu tersebut menjadi anggotanya. "Man is a social product"..$^{30}$

Proses internalisasi lebih bermakna penyerapan kembali dunia obyektif ke dalam kesadaran sedemikian rupa hingga subyektif individu dipengaruhi oleh struktur dunia sosial. Berbagai macam unsur dari dunia yang telah terobyektifkan tersebut ditangkap sebagai gejala realitas di luar kesadarannya, sekaligus sebagai gejala internal untuk kesadaran. ${ }^{31}$ Melalui internalisasi, manusia menjadi hasil dari masyarakat.

${ }^{29}$ Trio Hamdani. Produsen Masker Melonjak 200\% di Tengah Pandemi Corona. Selasa, 05 Mei 2020 14:14 WIB. Dari: https://finance.detik.com/industri/d-5003092/produsen-maskermelonjak-200-di-tengah-pandemi-corona

30 Mundiri, Logika, (Jakarta: Raja Wali Pers, 2010)., 21.

${ }^{31}$ Sukidin Basrowi, Metode Penelitian Kualitatif Perspektif Mikro, (Surabaya : Insan (endekian, 2002)., 206. 
Dengan pemahaman semacam ini, realitas berwajah ganda atau plural. Setiap orang bisa mempunyai konstruksi berbeda-beda atas suatu realitas. Setiap orang yang mempunyai pengalaman, preferensi, pendidikan tertentu dan lingkungan pergaulan yang berbeda akan menafsirkan realitas sosial itu dengan konstruksinya masing-masing. ${ }^{32}$

Sebagaimana yang terjadi saat ini, internalisasi masyarakat telah mengalami perubahan signifikan sebagai mana hal yang pertama: semangat komunitas. Terlepas dari kenyataan bahwa kebanyakan orang dikurung di rumah, banyak orang yang berada di suatu komunitas tidak pernah merasa lebih dekat daripada sekarang. Tanapa disadari, Ukhwah Islamiyah semakin menguat dalam kelompok-kelompok dengan semakin eratnya persaudaraan.

Kedua: Fokus kepada Pekerja. Para pekerja kasir supermarket dan jasa pengiriman pada umumnya tidak dianggap sebagai pahlawan. Tapi pandemi covid-19 telah membuka mata masyarakat dengan menyoroti peran penting yang dimainkan oleh pekerja sektor kunci tersebut. Apresiasi ditunjukkan secara terbuka, seperti memuji staf medis dan pekerja sektor kunci lainnya yang terus bekerja meskipun ada risiko kesehatan. Tiba-tiba, para pekerja bergaji rendah ini mendapatkan penghargaan yang layak mereka terima.

Ketiga: Perubahan Kebiasaan Kerja. Banyak pekerja membawa pulang pekerjaan kantor mereka. Beberapa pekerjaan tidak dapat direplikasi secara online, contohnya seperti kasir super market dan tenaga medis tadi. Banyak orang menghemat waktu serta uang dengan tidak bepergian, Baik itu perjalanan pribadi sehari-hari

\footnotetext{
${ }^{32}$ Sukidin Basrowi, Metode Penelitian Kualitatif Perspektif Mikro, (Surabaya : Insan Cendekian, 2002).199-200.
} 
maupun untuk pertemuan bisnis. Ini terjadi di seluruh dunia. Waktu tempuh itu sekarang dapat digunakan untuk menyelesaikan lebih banyak pekerjaan, meningkatkan aktivitas ibadah, atau sekadar bersantai di rumah.

Perubahan dalam kebiasaan kerja juga dapat mendorong pengusaha beralih dari model bisnis yang sudah ketinggalan zaman, yang terlalu bergantung pada pertemuan tatap muka. Teknologi seperti Zoom dan Microsoft Teams memberi potensi alur kerja dan produktivitas yang lebih ramping dan sederhana sehingga memberikan ruang dan waktu yang lebih luas untuk beribadah.

\section{Konstruksi Sosial Keagamaan Masyarakat pada Pasa Pandemi Covid-19} dalam Perspektif Tasawuf

Secara teologis perlu kiranya diyakini bahwa tuhan sedang menguji hambanya melalui mahluknya berupa Covid-19 ini. Sebagaimana yang tertuang dalam surah Al-Baqarah ayat 155, yang artinya: dan sungguh akan Kami berikan cobaan kepadamu, dengan sedikit ketakutan, kelaparan, kekurangan harta, jiwa dan buah-buahan. Dan berikanlah berita gembira kepada orang-orang yang sabar.

Dalam etika berdasarkan pandangan dalam kajian ilmu tasawuf, dengan adanya wabah Covid-19 seyogyanya manusia harus sabar dan shalat sebagimana firman Tuhan dalam surah Al-Baqarah: 45, yang artinya: Jadikanlah sabar dan shalat sebagai penolongmu. dan Sesungguhnya yang demikian itu sungguh berat, kecuali bagi orangorang yang khusyu. Memahami istilah "di rumah saja" pada masa pandemi, dalam kajian ilmu tasawuf setidaknya masyarakat Indonesia bisa belajar beberapa hal, di antaranya: 33

33 Santi Sopia. Istilah yang Muncul Saat Wabah Corona, Apa Saja?. Sabtu 21 Mar 2020 15:59 WIB. dari: https://republika.co.id/berita/q7jczy463/istilah-yang-muncul-saat-wabah-corona-apasaja 
Pertama: sabar. Ada pun yang dimaksud sabar adalah berusaha meneguhkan jiwa dalam menghadapi segala sesuatu yang memberatkannya dalam bertasawuf, termasuk wabah penyakit Covid19.34 Sebagaimana kesulitan yang dialami karyawan ter-PHK yang mencapai angka 1.722.958,35 yang berdiam di rumah, yang belajar secara online, yang pembatasan kerja dan yang khawatir terinfeksi Covid-19.

Kedua: syukur. Al-Junaid berkata: Syukur adalah kamu melihat dirimu sebagai pemilik nikmat. ${ }^{36}$ Seberat apa pun pandemi ini telah merubah kebiasaan mulai dari sektor ekonomi yang bersifat duniawi, hingga ibadah yang bersifat ukhrowi.

Ketiga: tawakal, menyerahkan atas segala sesuatu. Orang yang tawakkal (mutawakkil) akan melakukan perintah-perintah-Nya secara maksimal. Ada pun hasilnya atau akibatnya akan ia serahkan kepadaNya kembali. Sekuat apa pun keinginan tidak akan dapat menembus pagar ketentuan Allah. ${ }^{37}$

Keempat: muhasabah (introspeksi diri). Pada hakikatnya muhasabah adalah menghitung masa lalu untuk masa depan yang lebih baik. Dalam bertasawuf, manusia mungkin masih banyak kekurangan dan kesalahan yang menimbulkan kerugian. Bahkan mungkin saja wabah Covid-19 ini merupakan kerugian akibat dari kekurangan dan kesalahan yang dlakukan manusia sendiri. Sebagaimana firman Tuhan dalam surah An-Nisa ayat 79, yang artinya: apa saja nikmat yang kamu peroleh adalah dari Allah, dan apa saja bencana yang menimpamu, maka Akhlak:75.

${ }^{34}$ Bustomi, J., Setiawan, C. (2020). Ilmu Akhlak Menyingkap Misteri Tasawuf Menoreh

${ }^{35}$ Heru Margianto. Badai PHK di Tengah Corona Kompas.com 04/05/2020, 09:23 WIB dari: https://www.kompas.com/tren/read /2020/05/04/092323965/badai-phk-di-tengahcorona?page=1 )

${ }^{36} \mathrm{Al}$-Qusyairi, A. Risalah Qusyairiyah. Al-Haramain. 174.

${ }^{37}$ Athaillah, I. Al-Hikam. Indonesia: Dar Ihya al-Kutub al-Arabiyah. 6. 
dari (kesalahan) dirimu sendiri. Kami mengutusmu menjadi Rasul kepada segenap manusia. Dan cukuplah Allah menjadi saksi.

\section{SIMPULAN}

Ada pun simpulan dalam penelitian ini ialah, eksternal masyarakat melakukan perubahan sosial karena adanya informasi-informasi terkait pandemi Corona, baik melalui gugus tugas yang dibentuk pemerintah maupun dari berita-berita yang beredar di televisi maupun media sosial. Oleh sebab itu, masyarakat melakukan objektivasi dengan pembentukan perilaku yang dilakukan secara implisit untuk menanggapi peraturan pemerintah maupun berita yang beredar di media sosial yang diterimanya. internalisasi yang dilakukan masyarakat dengan memetik hikmah dalam setiap keadaan yang terjadi.

Selanjutnya dari konstruksi sosial keagamaan perspektif tasawuf pada masa pandemi dari sisi teologis diyakini bahwa Tuhan sedang menguji hambanya melalui mahluknya berupa Covid-19. Lebih lanjut terkait konstruksi sosial keagamaan perspektif tasawuf pada masa pandemi mengasilkan pola perilaku agama: sabar, syukur, tawakal dan muhasabah.

\section{REFERENSI}

Abu Sahma Pane. Pro Kontra Larangan Sholat Jumat di Tengah Wabah Corona. Kamis 19 Maret 2020 16:37 WIB dari: https://www.okezone.com

Ade Nasihudin Al Ansori. Perubahan Perilaku Masyarakat yang Terjadi Selama Pandemi COVID-19 di Indonesia. 20 Mei 2020, 09:00 WIB. dari: https://www.liputan6.com

Alokasi anggaran sebesar Rp 405,1 triliun guna penanganan Covid-19 dinilai Eko BeritaSatu.com dari: https://www.beritasatu.com Al-Qusyairi, A. Risalah Qusyairiyah. Al-Haramain. 
Athaillah, I. Al-Hikam. Indonesia: Dar Ihya al-Kutub al-Arabiyah.

Bustomi, J., Setiawan, C. (2020). Ilmu Akhlak Menyingkap Misteri Tasawuf Menoreh Akhlak.

Cahyo Prayogo. Virus PHK Tak Kalah Seram dari Virus Corona. Minggu, 10 Mei 2020 12:58 WIB dari: https://www.wartaekonomi.co.id

Dedy N Hidayat, Konstruksi Sosial Industri Penyiaran: Kerangka Teori Mengamati Pertarungan di Sektor Penyiaran, Makalah dalam diskusi “UU Penyiaran, KPI dan Kebebasan Pers, di Salemba 8 Maret 2003

Dian Erika Nugraheny. Mendagri Keluarkan Surat Edaran soal Pembentukan Gugus Tugas Penanganan Covid-19 di Daerah. Kompas.com - 30/03/2020, 11:23 WIB. dari: https://nasional.kompas.com

Ellyvon Pranita. Diumumkan Awal Maret, Ahli: Virus Corona Masuk Indonesia dari Januari. Kompas.com - 11/05/2020, 13:06 WIB dari: https://www.kompas.com/

Fitria Chusna Farisa. MUI Imbau Penundaan Sementara Shalat Jumat di Kawasan Berisiko Virus Corona. Kompas.com - 20/03/2020, 11:38 WIB dari: https://nasional.kompas.com/

Ghofur, A. (2019). Dakwah Islam Di Era Milenial. Dakwatuna: Jurnal Dakwah dan Komunikasi Islam, 5(2), 136-149.

H.M Burhan Bungin, Sosiologi Komunikasi: Teori Paradigm dan Diskursus Teknologi Komunikasi di Masyarakat, (Jakarta: Prenada Media Grup, 2008), 193.

Haky. Masih Banyak Warga Tidak Patuh Aturan Pemerintah untuk Lawan Corona. Senin 06 April 2020 18:30 WIB. Dari: https://megapolitan.okezone.com

Heru Margianto. Badai PHK di Tengah Corona Kompas.com 04/05/2020, 09:23 WIB dari: https://www.kompas.com/

Heru Margianto. Badai PHK di Tengah Corona Kompas.com 04/05/2020, 09:23 WIB dari: https://www.kompas.com/ 
Jenal Bustomi., Siti Sanah., Zulli Umri Siregar. Menyikapi Wabah Penyakit Covid19 Dalam Bertasawuf. Fakultas Tarbiyah dan Keguruan UIN Sunan Gunung Djati Bandung

Mala, F. (2020). MENGKAJI TRADISI NABI SEBAGAI PARADIGMA DAKWAH YANG RAMAH. Dakwatuna: Jurnal Dakwah dan Komunikasi Islam, 6(01), 104-127.

Merlion Gusti. Batal Haji Akibat Pandemi Corona, Kemenag Batalkan Haji Tahun 2020. Rabu, 3 Juni 2020. 11:27 WIB. dari: https://www.kompas.tv

Mundiri, Logika, (Jakarta: Raja Wali Pers, 2010).

Peter L Berger dan Thomas Luckman, Tafsir Sosial atas Kenyataan, (Jakarta : LP3S, 1990).

Promkes Kementerian Kesehatan RI dan Perhimpunan Dokter Paru Indonesia. Informasi Tentang Virus Corona. dari: https://stoppneumonia.id

Rachman, R. F. (2018). Dakwah Intraktif Kultural Emha Ainun Nadjib. Jurnal Spektrum Komunikasi, 6(2), 1-9.

Rachman, R. F. (2018). Perspektif Karen Armstrong Tentang Islamofobia Di Media Barat. Dakwatuna: Jurnal Dakwah dan Komunikasi Islam, 4(2), 282291.

Santi Sopia. Istilah yang Muncul Saat Wabah Corona, Apa Saja?. Sabtu 21 Mar 2020 15:59 WIB. dari: https://republika.co.id/

Sukidin Basrowi, Metode Penelitian Kualitatif Perspektif Mikro, (Surabaya : Insan Cendekian, 2002).

Thohir, M. M. B. (2020). Manajemen Dakwah Dalam Meningkatkan Perilaku Beribadah Santri Pondok Pesantren Darun Najah Petahunan Kecamatan Sumbersuko Lumajang. Dakwatuna: Jurnal Dakwah dan Komunikasi Islam, 6(01), 1-23.

Tim Gugus Tugas Percepatan Penanganan COVID-19. 6/11/2020. Dari: https://covid19.go.id/ 
Tim Hikmah detikcom. MUI Jelaskan Hukum Tak Sholat Jumat 3 Kali Berturutan Karena Virus Corona. detikcom - detikNews. dari: https://news.detik.com/ Trio Hamdani. Produsen Masker Melonjak 200\% di Tengah Pandemi Corona. Selasa, 05 Mei 2020 14:14 WIB. Dari: https://finance.detik.com Yayan isro roziki. Dilema, Sejumlah Kades Enggan Salurkan BLT Masyarakat Terdampak Corona, Khawatir Ada Konflik Sosial. Sabtu, 18 April 2020 16:05 dari: https://banyumas.tribunnews.com

Yosa Shinta Dewi. Terungkap Fakta Baru Terkait Ganasnya Virus Corona, Pasien Covid-19 di Kota Wuhan Alami Perubahan Warna Kulit, Seperti Terbakar dan Sangat Gelap. Selasa, 21 April 2020. 09:58 WIB dari: https://hits.grid.id/read/

Zahrotul Oktaviani/ Red: Muhammad Fakhruddin. MUI: Pelaksanaan Tarawih Menyesuaikan Kondisi di Daerah. Rabu 22 Apr 2020 16:13 WIB. dari: https://republika.co.id 